\title{
НЕКОТОРЫЕ ВОПРОСЫ ОППОРТУНИЗМА В БАНКОВСКОМ СЕКТОРЕ РОССИИ
}

\author{
(c) 2020 Вишневер Вадим Яковлевич \\ кандидат экономических наук, доцент \\ Самарский государственный экономический университет, Россия, Самара \\ E-mail: ab3535@mail.ru
}

В статье рассматривается проблема оппортунизма в банковском секторе России. Показаны основные проявления оппортунизма на микро-, мезо- и макроуровнях.

Ключевые слова: оппортунизм, банковский оппортунизм, оппортунистическое поведение, принципал, агент, оппортунизм на микроуровне, оппортунизм на мезоуровне, оппортунизм на макроуровне.

Оппортунистическое поведение субъектов экономики является одной из острых проблем в России. Оно проявляется в деятельности экономических агентов во всех сферах хозяйственной жизни [1]. Под оппортунистическим поведением понимаются решения экономических агентов, направленные на получение выгоды за счет контрагента, путем уклонения от выполнения норм и правил [2].

Причины оппортунистического поведения:

- обстоятельства, которые делают оппортунизм возможным;

- факторы, которые определяют готовность экономических агентов воспользоваться возможностью оппортунистического поведения.

Анализируя оппортунистическое поведение в банковской сфере, следует выделить микро-, мезо- и макроуровни. Микроуровень характеризует оппортунизм внутри банка, мезоуровень - оппортунизм во взаимоотношениях между банками, банками и клиентами банков. Оппортунизм на макроуровне затрагивает отношения коммерческих банков и Центрального банка [3].

В настоящее время оппортунистическое поведение в банковской сфере проявляется в следующих формах:

- лоббирование своих интересов путем обмана;

- злоупотребления доверием;

- введением контрагента в заблуждение;

- использование неточной информации.

Также рассматривая данную проблему стоит обратить внимание на такие явления, встречающиеся на банковском рынке регулярно:

- воровство имущества банка собственными сотрудниками;
- мошеннические действия с их же стороны;

- использование своего служебного положения с выгодой для себя.

Можно выделить 3 группы оппортунистического поведения в банковской сфере:

- правонарушения, которые совершаются клиентами или другими лицами;

- злоупотребление со стороны служащих данной финансовой организации;

- преступления, которые совершаются руководящими лицами, работающими в банке.

К ним можно отнести разглашение коммерческой тайны, сговор с целью получения личной выгоды от работы банка, использование инсайдерской информации для получения выгоды на рынке ценных бумаг.

Оппортунистическое поведение на банковском рынке достаточно глубоко описывается с помощью институциональной теории «принципал-агент» [4]. Например, некое физическое лицо, заинтересованное в получении кредита, обратилось к сотруднику банка за консультацией, чтобы прояснить все детали, связанные с выдачей кредита. Физическое лицо хочет получить кредит под наиболее низкий процент, чтобы сэкономить на выплате процентов по взятым на себя обязательствам. Сотрудник банка планирует получить максимум прибыли от заключаемой сделки и поэтому он от лица банка предлагает потенциальному клиенту четыре вида кредитных продуктов с дифференцированными процентными ставками. При этом не предлагается сразу наиболее выгодный вариант кредитного договора для клиента, так как это не соответствует коммерческому интересу финансовой организации. Действуя таким оппортуни- 
стическим методом, сотрудник банка сознательно создает ситуацию, при которой у банка есть возможность получить дополнительную прибыль за счет клиента, путем скрытия полной и объективной информации, либо доводит ее так, чтобы получить ожидаемый эффект с большей вероятностью.

Оппортунизм со стороны клиента банка - юридического лица может проявляться путем предоставления недостоверной информации, прямого обмана [5]. Так может искажаться информация о размере уплаченных налогов. Коммерческий банк для уменьшения риска потерь всегда должен анализировать признаки неблагонадежности клиента. Для получения бизнес-кредита компания должна отвечать таким требованиям: иметь статус коммерческой (НКО - не может претендовать на кредит), являться резидентом РФ, бизнес должен существовать не меньше шести месяцев для получения гарантии от банка и также не менее одного года, чтобы рассчитывать на выдачу кредита, иметь стабильный доход и положительную кредитную историю. Кроме того, сами коммерческие банки имеют право разрабатывать и устанавливать свои требования и сроки для заёмщиков.

Принято считать, что срока шесть месяцев и один год соответственно достаточно, чтобы объективно оценить дальнейшее развитие бизнеса. Если компания зарабатывает прибыль неравномерно в течение года, банк должен при выдаче кредита такому клиенту учитывать фактор сезонности, чтобы согласовать график платежей и не нанести вред своим коммерческим интересам. Кроме того, компания - заемщик предоставляет в обеспечение банку гарантии возвратности кредитных средств.

Одним из главных доказательств платежеспособности клиента банка является обеспечение залога или наличие поручителя. Поручительство требуется, если заемщик самостоятельно не сможет погасить задолженность. Особое внимание при выдачи любых займов уделяется прошлой кредитной истории заемщика.

У заемщика должны отсутствовать просрочки по предыдущим займам, недопустимо иметь отрицательную кредитную историю, задолженности перед налоговыми органами РФ, иски в арбитражных судах, наложенных и неоплаченных штрафов, опротестованных векселей. Компания не может находиться в стадии банкротства, а также не готовиться к ликвидации.
Служба безопасности банка должна обратить внимание и на такие признаки неблагонадежности клиента:

- частые изменения в реестре владельца компании;

- большое количество операций возврата поставленной продукции;

- компания может являться малым предприятием, но работает с крупными фирмами;

- физические лица, работающие в компании, начинают покупать дорогие транспортные средства, недвижимость, которая не соответствует их уровню дохода;

- у компании полностью отсутствуют основные средства;

- компания систематически использует иностранную рабочую силу без разрешения;

- отсутствует или подходит к концу срок лицензии на определенные виды деятельности.

Следующим видом оппортунистического поведения на банковском рынке считается не исполнение условий, прописанных в контракте одной из сторон [6]. К примеру, гражданин взял потребительский кредит у банка и не стал его возвращать. Таким образом, гражданин, не выполняя возложенные на него условия, прописанные в контракте, извлек для себя выгоду, нанеся ущерб банку.

Кроме всего выше перечисленного во взаимоотношениях между сторонами встречаются «контрактные дыры». Такая ситуация возникает в случае если в договоре не указано условие, которое по мнению одной из сторон является очевидной «истиной». Может быть также и искажение информации. Сокрытие и искажение информации наблюдается при заключении договора между банком и взявшим кредит, либо пользующихся другим продуктом клиентом [5]. Клиент банка оформляет карту для ввода средств на брокерский счет, карта нужна ему только в этих целях, банк же заинтересован получить от каждого действия клиента определенное вознаграждение. Банк автоматически подключает при подписании договора SMS - оповещение. A чтобы отключить данную услугу клиент должен предпринять ряд самостоятельных действий. Тут возникает ситуация, когда банк, желая использовать неосведомленность гражданина, пользуется этим, и получает в течение определенного периода деньги за навязанные услуги, зарабатывая на невнимательности и доверии клиента. Примером такой невнимательности 
является мелкий шрифт в конце каждого договора. По статистике именно там написаны самые важные условия.

Существуют риски и угрозы оппортунистического поведения внутри самого банка [7]. В кредитно- финансовых организациях работают люди, которые могут иметь доступ к конфиденциальным данным, данным, имеющим особое значение для банка.

Самые типичные схемы оппортунизма на микроуровне, являющиеся проявлением мошенничества:

- оформление кредита без ведома клиента;

- перевод средств клиента на собственные счета;

- подделка данных о заемщике при оформлении кредита или одобрение кредитной заявки без соответствующего соблюдения закона;

- разглашение конфиденциальной информации в корыстных целях.

Оформление кредита без ведома клиента состоит в том, что, имея в распоряжении персональные данные клиентов, которым одобрен кредит, персонал банка может без сложностей оформлять займы на физических лиц без их согласия. Возможен также перевод денег менеджером банка, например, со счета ВИП -клиентов, на собственные счет. Практикуется подделка данных о заемщике при выдаче кредита.

Оппортунистическое поведение со стороны сотрудников банка может проявляться через, так называемые, «арифметические ошибки». Под видом сбоя системы или ошибки списываются средства со счетов клиентов. Это является одной из самых серьезных проблем мониторинга и контроля за деятельностью сотрудников банка.

За 2019 год более половины случаев мошенничества в банковской сфере происходило при непосредственном участии сотрудников банков.

Вследствие оппортунистического поведения сотрудников банков возникает репутационный риск финансовой организации. Это риск возникновения убытков из-за негативного восприятия банка со стороны клиентов, органов, осуществляющих надзор и иных заинтересованных сторон, а также риск отзыва лицензии и уголовного преследования.

Оппортунизм в банковской сфере на макроуровне часто связано с противоречиями институциональных интересов [8]. Проявлениями такого оппортунизма являются:

- проведение высокорисковой кредитной политики и завышение оценки своих активов;

- несоблюдение требований законодательства в области противодействия легализации(отмыванию) доходов, полученных преступным путем и финансирования терроризма;

- проведение теневых сомнительных и/или транзитных операций;

- проведение схемных сделок для уклонения от требований Банка России и /или сокрытия реального качества активов;

- деятельность, ведущая к утрате капитала;

- предоставление недостоверной, фальсифицированной отчетности;

- нарушение требований, предписаний, ограничений, запретов Банка России;

- неспособность своевременно удовлетворить требования кредиторов, потеря ликвидности.

\section{Библиографический список}

1. Недорезова Е.С., Вишневер В.Я., Кусков В.М. Институциональные проблемы развития российского банковского сектора. //Экономические науки. 2018, № 7 (158). С. 17-22.

2. Мартюкова, Е.Г. Оппортунизм как поведенческая модель в российской экономике // Вестник ИНЖЭКОНА. Серия: Экономика. 2012. Вып.3 (54). С. 386-388.

3. Мартюкова Е.Г. Оппортунизм в банковском секторе России: причины и последствия. //Ученые записки Петрозаводского государственного университета. 2012, № 7-1(128). С. 110-113.

4. Мартюкова, Е.Г. Место оппортунистического поведения в системе исследований новой институциональной экономической теории // Экономика и предпринимательство. 2012. - № 5 (28). - С. 332-338.

5. Вишневер В.Я., Хололов Г.С. Влияние асимметрии информации на банковскую конкуренцию и монополизацию в России. //Экономические науки. 2016. № 11(144). С. 77-80.

6. Гладких Е.Г. Оппортунизм в банковском секторе России. // Ученые записки Петрозаводского государственного университета. 2015, № 5(150). С. 92-98.

7. Михайлов А.М., Патрин С.М. Управление рыночными рисками розничного банка //Вестник Самарского государственного университета. 2015. № 5 (127). С. 104-110.

8. Mikhailov A., Vishnever V., Konovalova M. Institutional regulation as a form of institutional interests in the banking sector //International Journal of Economic Perspectives. 2015. T. 9. № 2. C. 23-27 